\title{
MODERN LEADERSHIP COMPARED TO HISTORICAL LEADERSHIP SHOWN BIBLICALLY
}

\author{
A Thesis \\ Presented to the Faculty of \\ California Polytechnic State University \\ San Luis Obispo
}

In Partial Fulfillment

of the requirements for the Degree of Master of Science in Agriculture

by

Forrest Jones

March 2011 
(C) 2011

Forrest Jones

ALL RIGHTS RESERVED 


\section{COMMITTEE MEMBERSHIP}

TITLE:

AUTHOR:

DATE SUBMITTED:

COMMITTEE CHAIR:

COMMITTEE MEMBER:

COMMITTEE MEMBER:
Modern Leadership Compared to Historical Leadership Shown Biblically

Forrest Jones

March 2011

William Amspacher, Dr.

Bill Kellogg, Dr.

Scott Vernon, Dr. 


\section{ABSTRACT \\ MODERN LEADERSHIP COMPARED TO HISTORICAL LEADERSHIP SHOWN BIBLICALLY}

Forrest Jones

This thesis is a comparison between modern leadership and historical leadership. Modern leadership has been differentiated from management since the early 1980's. Historical leadership is shown by Jesus Christ through the Bible, used as a historical text. Historical leadership was found to have two separate tools used by Jesus Christ which would be useful additions to what leadership today is. The first tool is submission to authority. Most people in positions that would be considered leadership positions do not feel that they need to follow anyone else. Often times they act contrary to a way they have been directed to, because they feel their opinion is the only valid one. The second tool is servant leadership. In addition to believing their opinion is the only valid one, most leaders today consider their own needs before others and are not willing to serve those who they see as their followers.

With the incorporation of submission businesses could function smoother, react quicker to challenges and less conflict would develop between leaders and their authority. With the incorporation of servant leadership, employee retention would increase, quality of work would increase and ultimately more goals would be reached.

Current leadership is much more effective in many areas of business than management. The differentiation between the two areas since the early 1980's has allowed many businesses to react quicker to a changing market place and ultimately become better businesses. Leadership in its current form is effective, but can we historically infer possible improvements through looking at the example of Jesus Christ historically shown in the Bible?

The conclusion is significant in the business world, because it shows that through servant leadership and submission a high degree of ethics and commitment is shown. The net result of the ethics shown in this manner will increase trust both inside the business and to others who interact with them. 


\section{TABLE OF CONTENTS}

Page

\section{CHAPTER}

$\begin{array}{ll}\text { I. INTRODUCTION } & 1\end{array}$

a. Problem Statement 2

b. Hypotheses 2

$\begin{array}{ll}\text { c. Objectives } & 2\end{array}$

$\begin{array}{ll}\text { d. Justification } & 2\end{array}$

II. LITERATURE REVIEW 5

$\begin{array}{ll}\text { a. Current Leadership Skills } & 7\end{array}$

i. Vision 7

ii. Communication 8

iii. Knowledge 10

iv. Enthusiasm 12

v. Encouragement 13

vi. Using Leadership $\quad 14$

vii. Motivation 18

b. Who Can Lead 21

c. Leadership Obligation and Responsibility 24

d. Community Leadership and Education 27

e. Use of Leadership Tools Morally 30

f. Servant Leadership 34

g. Christ's Use of Modern Leadership Tools 39

III. COMPARISON OF MODERN AND BIBLICAL LEADERSHIP 43

IV. ANALYSIS AND METHODOLOGY 48

V. CONCLUSIONS AND RECOMMENDATIONS 52

BIBLIOGRAPHY 54 


\section{Topic: "MODERN LEADERSHIP COMPARED TO HISTORICAL LEADERSHIP SHOWN BIBLICALLY"}

\section{CH. 1 INTRODUCTION}

Leadership is a concept that has been sought and discussed for a very long time. Leadership continually incorporates new ideas and embodies differing styles, ambitions and goals. Today people envision leadership as a necessary part of business. With global markets and the ever-changing wants and needs of consumers, the old methods of business are no longer sufficient. Like many skills, leadership incorporates a set of tools that can be used in either a beneficial or a detrimental way. Vision, drive, knowledge, experience and many other tools exist for the use of leaders.

Vision has been considered one of the most valuable tools for leaders in today's society. Some refer to vision as a goal or dream. How many times have you heard the statement “you've got to have a dream”? Vision sets the direction of movement for individuals or a group. Vision also lets leaders direct those they lead even when they are not around if they have imparted their vision to the individuals or group that follow them.

Enthusiasm, or possibly - drive - is another tool that the effective leader cannot be without. Drive pairs enthusiasm with movement or action. Enthusiasm is great, but sometimes people will be enthusiastic and get hooked on one topic. The movement part of drive will push for advancement of the idea even while a leader is being enthusiastic 
and encouraging. A leader's job is to set and accomplish tasks; if they do not keep a team on track towards a goal then they are not as effective as they have the potential to be.

Informational knowledge is not always a must for leadership, but it can be very important. Those they lead often do not respect leaders without knowledge, and as a result many very large problems can occur. General understanding of what an individual or group is working on can allow a leader to check to ensure that errors are not made or shortcuts taken. Knowledge and experience are similar, however experience often gives more credibility to a leader than knowledge alone. Experience often imbues a leader with knowledge.

Many people in the United States today believe in God. According to the Barna Research Group, about 69\% of the American population "believe in God when described as the all-powerful, all-knowing, perfect creator of the universe who rules the world today” (2007). In the same 2007 survey only 10\% of the American population was described as “Atheist or Agnostic”. Regardless of personal views most major religions around the world believe that Jesus existed and that the Bible is at least a historical reference even if they do not consider it completely accurate. The main biblical example of leadership is found in the person of Jesus Christ. Jesus embodied many of the leadership tools that are used today; tools that are considered today to be the core of true leadership. Jesus also used these and other skills to impart his wisdom and knowledge to those who chose to follow him. It is possible that with closer analysis we can find skills that will apply to the future of modern leadership. 


\section{Problem Statement:}

Can we infer possible improvements on current modern leadership skills, techniques and methods using Jesus Christ as a historical reference?

\section{Hypotheses:}

There are skills, techniques and methods of leadership that Jesus Christ used that are not well known or used in leadership today. The radical shift from leadership in the late 1970's to what leadership is today can still be improved upon by emulation of leadership techniques used by Jesus Christ. This incorporation and emulation of leadership techniques used by Jesus Christ will benefit the future of leadership, because modern leadership has moved towards this historical example of what leadership should be.

\section{Objectives:}

1) To identify the embodiment of leadership today, as well as the tools that a leader needs to succeed.

2) To identify what skills Jesus Christ used as a leader and compare those skills to what leadership is today.

3) To make supposition as to what new or changed leadership skills may occur in the future based on the historical reference of Jesus Christ.

\section{Justification:}

If in fact 69\% of United States Citizens believe in God, and one of the most accepted historical references to God is the Bible, then Jesus, both what he says and does in the Bible is a valid representation of historical leadership. 
Other World religions also believe that Jesus Christ had an impact. Judaism recognizes Jesus Christ as a valid historic person, they disagree with his claim to be the Son of God, however they do recognize his impact. Islam another major world religion believe that Jesus was a Prophet and they also in this recognize his work. With a large belief in God and a large belief in the person of Jesus Christ we can look at his example of leadership in the Bible and compare the stories of his life with leadership to find what he did differently that can be incorporated into leadership today. 


\section{CH. 2 LITERATURE REVIEW}

Since the early 1980’s there has been a change of thought from the view that managers are the leaders in the company, to a point where there is a distinction between managers and leaders. Many authors, including Tichy, who wrote a book titled The Leadership Engine, have documented this change in understanding the difference between leadership and management. Ideally there are people who can both manage and lead, but most people are not able to dynamically do both. Managers in today’s businesses tend to make sure that ongoing operations continue smoothly, and actively seek to keep the status quo operating smoothly. Leaders, on the other hand, can be disorganized, conflict-thriving people that actively seek to change business goals to meet our continually changing society. Due to the intrinsically differing actions of leaders and managers, strife can often arise.

The distinction between leadership and management has developed because of the active need to adapt in today's world market. As information is more readily available and world markets change at an increasing rate, there needs to be more people who have the initiative, drive and determination to seek new ideas and encourage people to think creatively, work harder and push to find new markets for new products. Although

business leadership has spurred most of the research on leadership and the skills needed 
to be an effective leader, leadership in general is one of the more vital parts of our society today. To effect and influence people today, leaders are being educated to understand that encouraging, growing and challenging people instead of simply directing them is needed to accomplish the tasks they are responsible for. This education of leadership has been transforming businesses since the early 1980’s.

The simplest definition of what leadership can be said in one word. "Influence" is what people who understand leadership understand it to be. Every day most people have some influence on someone else, regardless of who they are and what they do, so in a way we all are leaders to some extent. People who want to be leaders in their lives find that leadership isn't something that comes overnight but, as Maxwell points out, it is a continual process of learning to develop the tools needed to guide and influence people. Maxwell is a well-known author of several leadership texts including 21 Irrefutable Laws of Leadership. He is also a pastor and has been successfully operating four different organizations based on his leadership styles for several years now.

In the following sections the author will look at what leadership is seen as today, and why being a leader is a life long development, not just a destination achieved in a short time. After defining what leadership is today the author will look at Christ's example of leadership, and using Jesus Christ as a historical example of leadership compare and contrast the difference current and historical Leadership. Finally the author will identify any differences between past and present leadership tools and give supposition of what other leadership tools could have been employed in the past or what possible future leadership tools may emerge. The author will also discuss which leadership tools in the current view of leadership may hold more value in the future. 


\section{Current Leadership Skills:}

Many authors have written about leadership and while they may have subtle differences, most agree that there are several tools that a leader must have and continually develop. Leadership tools consist of Vision, Knowledge, Enthusiasm (Drive), Experience and people’s need for Encouragement.

Vision

The first tool that is often referred to as the most important skill or tool that a leader in today's society must have is that of Vision. A Vision or dream can give direction to a company or a department within a company. A Vision can define the growth of an organization or a segment of society. Vision sets direction and even if the goal becomes slightly different it is still the destination, a striving point.

Vision is given from the leader as a goal for the organization. Norman Wazler, who edited the book titled Rural Community Economic Development, stated that leaders were individuals that shared their interests and direction with the community. Wazler showed that without individuals imparting a vision to those around them we would not have the communities that exist today. In the United States the imparted vision for years has been a picture of local and national development, whether roads or communities we have all been led by the vision of creating, building and improving our country. A leader sets out a Vision and then inspires people to begin working towards that Vision. There are many instances where one person's dream has benefited society as a whole. America is itself a Vision. When the Declaration of Independence was drafted, the founding fathers instilled their Vision for a better tomorrow in soldiers and families across the States. Without that Vision the United States might still be under English rule. 
Without a goal or a destination other leadership tools will not be nearly as effective. Influencing people to work harder and think in a certain direction yield greater results because it limits the area of thought and effort. The main implication is that by instilling a Vision or goal in people, leaders limit the overall focus and direct more energy into a defined area. Without an overall Vision, people will not form a concentrated effort in any specific direction. Each will pursue his own idea of what is important and although new ideas may come, they will take longer to arrive at and will not be as well defined.

Imagine a military campaign where there is no goal. Eventually there may be a victory (though even a victory is impossible to fully describe without a goal), but each individual would feel that different objectives were more important than others. With a leader imparting a Vision and goal, victory could arrive much sooner because non-crucial objectives can be bypassed. And, by using a concentrated effort to attack, more battles would be won on the way to victory. Without Winston Churchill and Franklin Roosevelt inspiring their citizens and soldiers with their Vision, World War II might have turned out significantly different. Vision has been the defining quality in many leaders, and will continue to be a valuable leadership tool in the future.

\section{Communication}

Communication is more of a skill than a tool in leadership. Leaders can lead if they only use one or two tools (though they will not be as effective) but without communication a leader cannot succeed. Martin L. Van Creveld authored a book titled Command in War which was published by the Harvard University Press. In this book Van Creveld showed the importance of fast effective communication in war. Van Creveld 
also showed that effective and complete communication, whenever practical, will allow individuals or groups to respond quickly to a leaders request that requires immediate action because of the trust the leader has developed. Without effective communication, leadership becomes much more difficult. Errors are made and important ideas are lost. In many ways communication skills are as valuable as leadership skills and Van Creveld makes this point very clear. If a leader does not correctly communicate then the wrong tasks may be undertaken. Even if all a leader does is delegate they still need communication skills.

Military communication is much more direct than most communication used. Officers have been trained so that they understand how to accomplish their objectives and, if needed, understand the ultimate destination and make corrections to meet a final objective. Military communication is more direct because of the constraints of time and the urgency under which communication is done. If a military leader takes the time to imbue trust in those they lead direct communication is much more effective. In combat especially, if communication has been used and trust built the response to an imparted goal will be immediate and unquestioned. In the civilian world this is not the most effective method of operation. Using direct communication in the business world can remove many benefits derived from a much more open form of communication during a project; for example different ideas, more effective ways of implementing ideas and other items that open communication provides.

Communication can be very difficult to master. The saying that "you can please all of the people some of the time and some of the people some of the time, but not all the people all the time” applies to communication. Due to the way one communicates, they 
will alienate some people, and they will achieve better things with others.

Communication embodies many areas. Verbal and non-verbal communication can be broken apart and each separately analyzed. The main idea is this: each person communicates differently. An effective leader can look at an individual and begin to understand how to influence that person and communicate successfully with them. Granted, this will not always happen but the more skillful and practiced a leader, the less often communication problems will occur. Communication is a facilitator for leadership tools.

\section{Knowledge}

Knowledge is a tool that helps validate a leader to those who are being led. With knowledge, a leader can direct, supervise and assist. Without knowledge a leader is often limited to encouraging and providing the overall goal. Knowledge is an extremely effective tool for a leader. Sometimes however using the impression of a lack of knowledge can also improve effective leading ability. A leader can ask guided questions under the guise of not understanding that encourage a follower to think of certain aspects of an idea they have proposed which they may not have considered.

The value of knowledge is accepted by most of society. As a result education is widespread in the United States today. Cully A. Cobb, a politician from Mississippi, was able to use leadership education to create, and help the youth clubs of Mississippi succeed. Scott's example of leadership, in the creation of knowledge through informational teaching, shows that education and the sharing of information associated with leadership was seen to have value even before the 1980's. Leadership education is becoming more sought after today. Many universities have courses developed 
specifically to impart knowledge of leadership to the youth that are becoming educated today.

Knowledge in two distinct areas can impact a leader. First is the leader's actual knowledge of how to lead. If a well-seasoned leader undertakes to lead they understand how to impart a vision, and they realize that there are certain things that they may need to learn before working with a group, many of whom could be experts in a certain field. The second area a leader will need at least a basic level of knowledge is the subject matter in which they are leading. Without some subject matter knowledge the people led will not be as accountable to the leader, because there is less accountability. In addition if they know that the leader does not have any subject matter knowledge it is possible followers may not respect the leader. The best leaders are equipped with leadership knowledge, and then seek out topical knowledge for the specific area in which they will lead.

While knowledge is important it is not as crucial as communication. In today's society information is readily available, which is why knowledge of how to lead is more important than subject knowledge. Terry Pearce wrote Leading out Loud: The Authentic Speaker, the Credible Speaker. The topic of speaking is important to leadership because communication is a cornerstone and speaking is a large portion of communication. Pearce wrote:

The end of the modern era has brought with it a well-documented confusion of values and a substantial shake-up in fundamental beliefs. Much of the world's accumulation of the information is universally available, and as a result, the people with the most knowledge no longer have the same leverage to gain leadership positions. In fact, the seemingly unlimited availability of information offers more confusion, more possibilities, and the average person is left groping for certainty. (Pearce, 1995) 
When one can understand that information is available to everyone, and that new information is continually being produced, knowledge of how to find information becomes more useful to leaders than how to produce information, because they have instant access to it. This also makes leadership more crucial, because with rapid movement of information there are rapid changes in markets, or approaches to them. Leaders that have the knowledge to direct teams and to develop more leaders will find their organizations able to adapt more quickly to the changes in the age of information.

\section{Enthusiasm}

Many people who have studied leadership point to enthusiasm as a very useful tool of leadership. The author feels that enthusiasm in itself can be limiting and has chosen to refer to this tool of leadership as drive. Drive, in the author's opinion, takes enthusiasm into account and adds the element of movement to the concept. A leader has a responsibility to keep his or her team focused. When leading a creative team many things may occur including tangential movement from the subject matter. The leader must first identify these possible tangents and redirect the group back to the original goal. If this is done without enthusiasm the leader could lose his or her influence and possibly discourage beneficial creative thought.

Drive increases both the potential of the group being led and the potential of a leader to influence the group. If a leader is effective in re-directing wayward thoughts and ideas the first several times that deviation occurs, then the group will often learn how to keep enthusiastic, and on topic. This could free some of the leader's attention and almost allow him to participate in the group action as a member. 


\section{Encouragement}

Burt Nanus wrote The Leader's Edge: The Seven Keys to Leadership in a

Turbulent World. The concept of leadership in a turbulent world is important because the one constant in this life is change and variation. A leader must be able to take all things in stride and Nanus gives an example:

I once asked a colleague whether he was optimistic or pessimistic about the future of America. 'Both' he replied. 'How can that be?' I asked. 'Well' he said, 'I have always been an optimistic soul and, after all, things have usually worked out well for this country.' 'But then why are you pessimistic?' I persisted. 'Because,' he replied, 'there seems to be so little basis for my optimism!' (Nanus, 1989)

This statement shows that even in a situation where the seeming outcome is not uplifting and beneficial a leader can turn the topic to an encouraging point of view, possibly using humor. Encouragement is a tool that lets a leader combine enthusiasm with the responsibility of guiding and succeed in not alienating the people that they are leading. Encouragement can take on many forms and is part of the enthusiastic attitude needed to use the leadership drive tool. Many have mistaken reward as an encouragement of some kind and use rewards whether monetarily or non-monetarily as encouragement. In many situations rewards are not the appropriate form of encouragement, and if offered some being led may be offended.

Whicker, who tried to impart that leaders can be detrimental as well as beneficial, said: "The likelihood is great that almost everyone, at some point during the span of a thirty or forty-year career, will work in an organization dominated by a toxic leader” (Whicker, 1996). Toxic leaders are often the leaders that do not have the skill to bolster and improve their followers. Some times these leaders do extremely well, but there is 
usually some other motivator, like larger salaries. Leaders that do not know how to direct their followers in the direction needed, or who are too enthusiastic about every tangent idea usually do not do as well as leaders who are able to encourage, be enthusiastic and move the team forward.

\section{Using Leadership}

Teamwork has become an area of focus in recent years. In fact teamwork is one of the most highly prized skills that companies seek these days. Many team building facilities and companies based on building teamwork are available around the United States today. Educational institutions use a team project in almost every class. A discussion with a high school or college student today enumerates that most courses designate a portion of the syllabus for team designated work. In addition, large companies like Pepsi Co. have sponsored their own teamwork training facilities at the college level and in the business sector. The teamwork movement does not mean that teams can work well without a leader. Actually, these spotlight potential leaders while letting groups learn to follow as well as lead depending on the situation. Many authors talk about the time it takes to develop teams and leaders. Wall wrote to encourage potential leaders to continue to learn and grow in leadership. He stated:

This process won't happen overnight. It may take weeks, months, or even years. Don't let this deter you. For every challenge met along the way, there is a corresponding reward in the form of higher productivity, better work methods, and lower employee turnover. (Wall, 1992)

In many ways team building is being held at the top of what people consider leadership. Granted this is a valuable skill but it cannot be considered the end of the leadership issue. Other skills need to be developed and learned. Another side of this coin 
is the fact that some people work better alone than with a group, and depending on the task, the outcome might be better and faster with one individual.

Looking at teamwork, and the use of a group over an individual, what are the advantages? Dr. Scott Vernon, a professor at California Polytechnic State University, San Luis Obispo, tells his leadership class that one of the benefits to group work is that usually the more minds working on a problem the better the solution is. The downside is that it takes much more time.

There are obviously other differences in benefits and detriments when comparing teams and individuals. However, this statement spotlights the benefits of teamwork. In many cases the statement that with 12 people you will find 13 opinions is very valid. A leader's role can change dramatically depending on the team or group they are working with. As a matter of fact there are situations where a leader will have to appear not to be the leader. An example of this may be a group of experts that keep diverting from their task on tangential ideas. A leader would not want to stand up and tell everyone that they are in charge. A more effective course of action would be to keep bringing the team back to the subject matter, encouraging them on the topic and keeping everyone focused on the ultimate goal.

Another issue of teamwork is that some individuals, due to their personality, will not enjoy working in a team, and they will not feel comfortable or be productive in a team situation. Many people involved in leadership positions of today do not realize that knowing how to understand people and "influence" them with respect for their personal feelings is almost as crucial as Communication. Understanding how people think and 
interact with the world around them, what their personalities are etc. will allow a leader to communicate with those they lead.

Catherine Fitzgerald wrote with the intention of encouraging leaders to keep developing their skills when working with individuals to understand their personalities. Fitzgerald wrote regarding how individuals relate to others: "People may direct their energy and their attention primarily to the external world, which Jung called Extraversion; or primarily to the inner world of ideas, values, and experience, which Jung called Introversion" (Fitzgerald, 1997). Leaders need to be able to read and at least partially understand those they lead. Extraverts typically are much more comfortable in a group and will have an easier time focusing on the task at hand. Introverts may have significant issues in dealing with a team. A leader must understand those who follow them and work in a way that will allow all those who follow them to succeed.

Michael Maccoby had the idea that people in this and future decades would need a different kind of leader than the people in the past did. He emphasized that his opinion of a different leadership style was valid by stating that over a ten-year search, he had yet to find a leader who fulfilled the requirements he felt would be needed in the future. His assertion was that a leader needed to know how to evaluate others, understand different tools of leadership on a conceptual level and use his understanding to lead. Therefore understanding individuals will greatly aid a leader's job. Understanding people, their beliefs and desires, will help allow a leader to lead. But along with this comes a large level of moral responsibility that will be discussed later.

Knowledge as previously discussed, plays a big part in leadership because it allows a leader to either know how to lead or know how to show knowledge in certain 
areas that their followers are working in. After a leader has knowledge it is important that they have experience. While knowledge is not the precursor to experience it is often something more straightforward to obtain than experience and is very useful when gaining experience as it gives a basic understanding of the situation. Some of the most skilled individuals gained their knowledge through experience not separate from it. With experience comes the understanding of when to use the tools of leadership, how to evaluate followers, other leaders and people in general. With experience in leading a leader will be able to use their knowledge and experience in other areas to lead with many fewer conflicts. Experience in itself does not make or break a leader. The amount of experience simply makes the process less difficult and intense for the leader. Robert Taylor and William Rosenbach wrote Leadership: Challenges for Today's Manager where they sought to show managers how leadership would be a benefit both to them and their organization. They stated: “Administrators, managers, and leaders are all associated with the role of an executive. Over the years there have been many debates about leadership and management. Some people see them as the same. Others fervently believe that they are different” (Taylor, 1989). Typically in business today the upper echelons of business have as stated administrators and managers, people who influence and direct the individuals of a company or entity. These people who lead the company are seen as being in an executive role. The main task of these individuals whether they accomplish it or not is to lead the company. Most of the time these individuals are in the positions they are in because of their long standing with the company, combined with the experience they have gained over the years. 


\section{Motivation}

Many authors have written about motivational tools, and most if not all leaders know that their followers need to be motivated. Motivation increases performance and increases quality of work. If people enjoy doing something and feel like they do a good job they will do better work faster than if they feel like they do not know how to do something or that they do it poorly.

The concept of the "whip and the carrot” is known by many managers. You punish people for doing poorly — the whip—and you reward them for doing well—-the carrot. Many managers and leaders do not follow the correct model of correcting in private and building up in public. When you correct in public people usually get resentful because they are made to look bad. However, when you praise someone in public they often, in American society, are rather happy because they are made to look good before their peers.

An individual's culture and background can influence the way they respond to rewards and punishments. In many cultures that value the family unit or the group above the individual, people will not respond well to being singled out in public regardless of whether they are being rewarded or not. Part of this is because by being praised they are being singled out from the group, and since they value the group and their participation in the group over the individual they are often uncomfortable and unhappy.

Schmidheiny (1992) wrote a leadership text in which he challenged business leaders to understand the things around them. Followers are probably the most important part of this. By understanding the things around them a leader can respond correctly to those influences to achieve better results. The same is true of the people that they lead. 
If a leader knows an individual and understands some of the things that motivate them, then they can work to encourage that individual, making fewer mistakes to do so. One of the biggest barriers to this concept is that managers and leaders in the United States today think that the easiest way to motivate their followers is to offer them more money.

Abraham Maslow's hierarchy includes the need to belong. People need to feel like they are contributing, that they are of value and worth. When people feel worthwhile they will be able to be encouraged in more ways. Regardless, leaders must understand the individual and how the individual works before they can correctly encourage them. People want approval from those around them; children from parents, employees from bosses, followers from leaders and even peers from other peers.

Many leaders do not realize that a simple thank you can go a long way to motivating someone. A simple gesture like thanking someone lets them feel needed, tells them that they are a benefit and lets them know that the leader is paying attention. Done in private, this action will not single out anyone, and if a leader is new to a position it could allow them more time to understand the individual before having to motivate them in other ways. If a leader can focus a follower in another direction for a short time by vocalizing appreciation then they can take the time to learn about the individual and what would make them feel appreciated in other ways than with words.

Most followers want to be informed, they want to know what is coming. Many want to know so that they are able to do a good job and earn approval. Simply keeping people informed can be a way of motivating and encouraging them, because they feel worthwhile, that they are worth the leader's time and information. In most cases this does not take a significant amount of time and it sets the stage for trust. 
Leaders must learn that by using discipline constructively they can encourage people. Most correction and disciplinary actions taken by managers and leaders are not handled in a manner that builds morale in the long run. Properly used, discipline is a powerful tool for teaching and at the same time letting the follower feel needed and useful. John Lane wrote "Effective School Leadership" and focused on developing people. Discipline is a part of this developmental process; it must be part of the process, and done correctly can keep people motivated, encouraged and moving forward. While Lane's focus was entire schools, not individuals, he also mentioned that the "develop-theindividual” theory is becoming accepted and more understood. Knowing individuals, how to teach them and bringing them all together is what leadership is becoming.

Lane was focused in the right direction. Leaders need to teach the people around them. Leadership is a learned skill and, as Maxwell (1998) pointed out, someone’s effectiveness is in direct proportion to his or her level of leadership skill. This is true whether or not they use the leadership skills that they have. When leaders pass on what they know they will find that the effectiveness in their organization increases. This is a contradiction to many of today's business practices. Today people horde all the knowledge that they have trying to stay ahead of the other guy, and the concept of teaching them what you know is unheard of because they will then be in a better position to take your job. The concept that this is a "dog eat dog world" is well known and well practiced in America today.

In the United States today businesses usually have a very limited number of ways to reward people. Money is often seen as the only real motivation tool. The problem is that in many situations this kind of reward system is not motivational, and as Maslow 
stated, after a certain point monetary reward becomes counterproductive and that the individual would be much more encouraged by other methods (even just a thank you). Who Can Lead:

The questions of who are leaders and who can lead have been seen in the search for leadership since authors started researching and writing on leadership. The answers are that leaders are everywhere, and that anyone can lead. People often feel that they cannot be a leader unless they are promoted into a leadership position or until people agree to follow them. The truth is that most often the real leaders are not promoted into positions of leadership until after they are leaders in practice. In many cases the leader of a group is not the appointed or elected person. This is especially true today when the business world is continually plagued with lower retention and constant mergers. The best leaders realize that when they move into a new organization they may not be the leader, even if they are purported to be. Many leaders are never told directly by their followers that they will follow. Leaders set a course, whether in a void of direction or in spite of other directions, and people start following for one reason or another. The author has pointed out that leaders do not have to possess every leadership tool. People will follow a leader that does not possess a large amount of leadership skill, but as John Maxwell and other authors have pointed out, followers tend to follow the strongest leader in a group. In this way if the strongest leader is not the elected leader, the end result may be that someone else in the group ends up leading without anyone directly submitting to their leadership.

Many people have been taught that leaders are born and that without being born a leader they will not be very good or effective if they try to become such. As many 
authors and professors like Dr. Scott Vernon point out when educating new leaders, this is not the case. Almost the opposite is often true. The best leaders are individuals that realize that leadership is not a destination but a constant journey of self-improvement. It is true that some people are naturally more charismatic and as such tend to motivate individuals more easily. Some people are able to communicate more easily with people and do not need to constantly teach themselves how. The fact of the matter is that most of the time the best leaders are the ones who have dedicated a large portion of their lives to learning everything they can about how to lead from any source available. These leaders do not have a set of items that people who want to be leaders need to know, but rather, they have developed ways of incorporating their own personalities into leading and in fact each great leader is different from other leaders. Bob Stewart pointed out, in his activity guide titled "Leadership for the Agricultural Community” that, decisions are in everything that a leader does, and that a leader must make the choice to be a leader and to develop him or herself.

The best leaders are those who want to lead and actively develop themselves as leaders, but some do not want to lead. Individuals may have some skills as a leader, but simply will not lead because they do not want to. In many cases this is similar to individuals who value the group more than themselves. When someone is chosen as a leader they are separated from the group. If someone does not want to be in this position many things can occur. However, in the long run, the result is the same. The employee is unhappy and they most likely are doing a poorer quality of work. This still tells leaders that they need to know the people that work with them and follow them so that situations that can be avoided are. 
Each leader is different, just as each person is different. With different leaders different tools will be used with different skill levels. This does not necessarily mean that one leader is better than another or that one way of leading is better. William Cunningham co-authored a book called The Culture of Excellence in Education in which he pointed out that although all schools need to be led, to where they can produce better educated students, each school has different needs, individuals and ultimately will need to be led in a different fashion. He makes the point that in each situation it takes a different leader to interact with the "intricate tapestry in education today" (Cunningham, 1993). We have all heard the saying that the only thing constant is change, but it seems that few people before the mid 1980's had taken the time to evaluate what that meant in terms of leadership. Today it is better understood that leaders cannot be defined in certain terms and that different leadership styles are needed for different situations.

Most people have at least some leadership role in their lives whether they want to or not. Understanding that leadership is influence helps us realize that simply by interacting with friends and relatives one can end up as somewhat of a leader by swaying people’s opinion. Granted some people do not tend to voice all of their opinions, and often quieter people might say nothing at all, but at some point they will make a statement that influences someone to some degree, and in a way they have led the situation to a different point. Just because everyone is a leader at one point or another does not mean that everyone realizes it or likes doing it. As a human influence, leadership, is a part of life to one extent or another. 


\section{Leadership Obligation and Responsibility:}

With trust comes responsibility. When a follower does as a leader asks, the leader carries a certain responsibility. The leader needs to do what is best for others before what is best for him or her self. Many times the best for someone else will also be what is best for the leader, but anyone aspiring to lead needs to look out for those who follow as well as those whom they are accountable to. If leaders realize that they are responsible for others and act accordingly, they will find that people prefer to follow them because they have shown that they do what is right, not necessarily what is always beneficial for themselves.

Leaders need to set an example for everyone around them. For their bosses they need to show how to treat the people under them and accomplish overall goals set by others. For their followers they need to show a willingness to do the job at hand and a willingness to submit to the authority above them as an example. Walter Wilcox wrote about social responsibility in leadership, specifically in farm leadership. Without responsibility, leaders can cause followers to destroy the things around them. This damage can occur if the individual in the position of authority shows those who follow that they care more about themselves than those around them or the task needing to be accomplished. This will have the potential to push those following to think more about what is best for them as individuals and not the team, entity or task.

Ezra Taft (Wilcox, 1956) stated that “The supreme test of any government policy, agricultural or other, should be; how will it affect the character, morals, and well-being of our people?” This rings true today in government, but more than that the leaders in all 
levels of our society need to stand up and hold the government as well as themselves to this level of responsibility.

More than this, people will not follow someone that benefits him or herself to the detriment of those who follow them, for very long. Maxwell used the visual picture of what he called "Leadership Change”. If a leader acts responsibly and in others' best interests as well as their own, people will trust and have more faith in that person, in essence adding change (like a currency) to the person’s leadership pile. If however a leader makes a mistake, or if they act in a manner contrary to the benefit of those who follow them, it costs them some of that change. Eventually if a leader acts in this manner or keeps making mistakes there will come a point where others will no longer follow them, even if the error is rather small. The concept is that of "the straw that broke the camel's back".

Leaders need to be able to understand their followers, to be able to tell if there is a conflict or problem and to try and help them solve it. If a leader is able to recognize when an employee or follower is experiencing difficulties, specifically, in other areas that may or may not affect their performance, then the leader will be able to aid the follower in overcoming the problem. If a leader is effective in this manner, the people that follow them will be able to continue being productive, and will have a stronger feeling of responsibility. Understanding one's followers is a skill that will increase productivity and increase the duration for which it can be sustained. This is important to a leader because most of the time they themselves are followers or employees who are accountable. Even if a leader is not responsible to a higher human authority, increased production and sustainability are some of the goals that businesses search for. 
Some of the responsibilities that leaders have to people with higher authority are tangible, and some are similar to those intangible responsibilities that they have to those who follow. Leaders have a responsibility to accomplish goals. These can be set by themselves or by their authorities. Leaders also have an obligation to do things to the best of their ability.

Leaders have an obligation to develop their followers. When a leader develops someone who follows them they are increasing the potential of the whole group. Some people do not want to develop their leadership skills, and some leaders see the concept of imparting leadership to others in a bad light, because today business seems to be based on the "one up" concept. Many people in business today think that they have to protect their position or someone will take it from them, and the best way to protect it is not to train those who follow.

Leaders have a responsibility to pay attention to their followers. Often followers will have good ideas that a leader will miss. The old concept of the more minds the better often applies but is not used, because a leader is afraid that their job will be stolen if someone has a better idea than they do. Many leaders do not feel that they should take an active role in whatever they are leading. Often if managers are asked what they do, will answer with some statement similar to "I manage". The best thing for a leader to do is to take an active role in what they are leading. Leaders have an obligation to lead by example because if they are not willing to do a task how can they expect someone else to do it?

Leaders are often people who have had a larger amount of experience in their lives. With experience can come many things, and hopefully patience is one of them. 
Leaders need to realize that most who will follow them probably do not have the same knowledge as they do and as such may not find the same things as simple and straightforward. They, as leaders, have an obligation not only to be patient but also to help and teach. Obviously this is not always possible, but the best leaders find ways to teach as the task is being accomplished.

Once again the best policy for leaders is to train leaders who in turn are not just leaders, but people who develop other leaders. This seems contrary to what is seen in business today. As the author mentioned earlier and others have continually pointed out, in business today leaders and managers do not like to give followers all of the tools they need. They do not want to teach and train people, because in doing so they feel that their job is threatened. The only sure way to keep ahead is to kick people off of the ladder of success, not to build them up and help them grow. But, if a leader understands that they have obligations and responsibilities to both the people they follow and the people that follow them, the outcome will be significantly better.

\section{Community Leadership and Education:}

Leadership has been involved in the creation of many community organizations. Without leadership our educational system would not be in place as fully as it is today, and organizations that help youth might not exist. The Boys and Girls Club, the YMCA and the PTA are all organizations that have emerged because someone had a vision and set out to inspire others with that vision. Farm clubs and many other rural organizations would not continue to function at all without community leadership and involvement, simply because without inspiring people to be involved there would be nothing to meet about and nowhere to do it. Rural communities need to take more of an active role in 
developing their own programs, because most are too small for any of the large, mainline organizations that focus on larger communities.

For the most part community leadership is not used to develop new leadership, it is a forum to display leadership, or to control. Realizing that any good leader will develop those around them regardless of whether they intend to or not, we must accept that the purpose of community leadership is to accomplish something that the community needs. A small group of individuals gets others in the community involved and use their influence to solve a problem or fill a need that they see in their community.

Politics in many ways is not leadership. Obviously elected officials often fill what we call a public leadership position but for the most part what they do is not leadership. Community leadership tends to be found in smaller groups, mostly disconnected from what we see as public leaders. Many do not feel represented by their elected officials. Unfortunately today many feel that the public servants in office have forgotten their responsibility to those who follow them and many carry on in smaller groups, accomplishing what they can.

When dealing with community leadership, interested people tend to gravitate toward whoever has the vision. People are not forced to be in the group, individuals can associate themselves if they choose. As a result many leaders are not trained as leaders and may lack the skills to understand their followers. Often the residents of a community will already share some common points of interest, and all that is needed is one individual, to guide and focus the community (Wazler, 1991). Another reason that many community leaders attract people with a similar view and agenda is that much of community leadership focuses on the youth of the community. Youth focus many of the 
people in the community, because most people see children as their legacy, and youth need direction. Granted there are many other community programs, typically speaking these programs are not lead by community members, they are directed from a political level.

Community level education of leadership is key to the perpetuation and the development of our nation and businesses. Lao Tzu said that if you "give a man a fish you feed him for a day. Teach a man to fish and you feed him for a lifetime” (Lao Tzu, 1972). Education of leadership has much the goal which is to teach leaders who educate new leaders, etc. If a business wants success and progress they need to build leaders in all levels of their organization. Unlike management, leadership is not something that you can have too much of. Leadership skills increase the potential of the organization as well as the individual. Education perpetuates the growth of leaders, as well as increasing each leader's skill and capability. Maxwell (1998) wrote about this concept of having all the leaders possible, and he stated that naturally weaker leaders tend to follow naturally stronger leaders, which brings group cohesion.

Leadership is a lifelong journey, and while educating other leaders is needed, the other vital need in leadership is to continue learning about leadership and the people being led. Perhaps continued education is a better term, because leaders need to remember to keep searching and striving for better leadership skills. Businesses have begun to require continued education. With leaders who continue to learn, businesses are able to change with increasing speed to what consumers around the world want. This allows businesses to continue to succeed in a marketplace that becomes more global on a daily basis. Today leadership is being taught in universities and in higher education 
settings. Leadership is becoming a part of almost every higher education student's curriculum in the form of team projects. Debra L. Smarkusky wrote that team projects need to be incorporated into every course in the computer science and IT Curriculum at Pennsylvania State University. Research papers like the one she wrote in 2004 with Harold Smith have been a driving force to the incorporation of more and more team based projects to increase communication and other skills.

Companies like Pepsi Co. have invested millions into training leaders so that they can adapt to what the customers want and need. Many companies continue to invest in this area, because they realize that in many ways leadership is not just about monetary returns, it is about simply surviving.

Leadership education perpetuates success. Leaders become better workers, and many other benefits can be seen in the use of leadership, but still many resist the concept of growing leaders. Why? More leaders equates to less power for the current authority. Many CEO's do not want to delegate, or share any of their power even if the returns to the company outweigh any personal loss.

Use of Leadership Tools Morally:

This section obviously ties in with obligations and responsibilities. If a leader acts morally and with a code of conduct then they will fulfill their obligations and responsibilities. If a leader does not act morally then they will most likely neglect others for their own benefit. Followers can tell if a leader lives and acts morally or with a code of conduct, and they will for the most part respond accordingly.

Francis Aguilar wrote a book entitled Managing Corporate Ethics. In this book he states that the predominant problem in dealing with ethics is that eventually a leader may 
get to a point where they feel that if they just cross the line "this one time" the benefit will be much more than the cost. The problem with this decision is that the cost will always be more than the benefit even if it is not apparent immediately. If a leader acts in this manner once and is not called to account then they are likely to rationalize the next time they feel similar, and the downward spiral will continue. Aguilar (1994) stated that the best way to keep leaders ethical was to strictly define what the company ethics are. Tichy (1997) spoke of several situations in his book that were along similar lines. He gave an example of a company that had a faulty product and a well-defined set of ethics. Each manager and leader followed the ethical guidelines. They took responsibility and recalled their product. The end result was that they did not have major setbacks like another example Tichy gave where the company tried to cover the evidence.

If a leader acts morally it builds the groundwork for people's trust in them. As previously mentioned in the section on obligation and responsibility, people will be much more willing to follow a leader that acts as they should instead of just in a way that is beneficial to themselves. Today trust is becoming a scarce commodity. How many people do what they say? Not many people follow through with what they say, and sometimes even if they have signed a contract or other binding document they will not follow through. If a leader acts morally they set a standard for those who follow them. They will hold their followers accountable and eventually people in higher authority will notice and most likely imbue more trust and authority in them. Leaders that act morally will not always see the benefit in the moment, but it builds the future for them, their followers, and the business in which they work. Often leaders are the most visible people to those outside the organization, and how they act determines how a business is 
perceived. Someone once stated that, "good news travels fast, but bad news like wildfire.” This is even true in big businesses that span countries and the world. Maxwell mentioned the "Leadership Change” concept. Conceptually leaders will try their best, but inevitably they will make a mistake. A leader's action up until the point where they make the mistake often can tell the outcome of that mistake. If a leader has acted morally and ethically, fulfilling their obligations and responsibilities, then most likely they will survive even a monumental error. In contrast, if a leader has not acted morally, shirking responsibilities and obligations for self-gain, then even a small mistake can bring destruction. Over the longrun people will not follow a leader if that leader does not act morally.

Acting morally builds trust and belief in a leader's ability. Leaders cannot grow in influence or effectiveness if they are unable to get their followers and those with authority over them to trust and believe in them. In essence a leader cannot grow if they do not act with a continuous high moral standard. In many ways followers also want consistency. If a leader acts morally one day and in their own best interests the next, people around them will become frustrated with the lack of consistency. When leaders do not act consistently followers will complain and dissent will form.

If a leader acts morally their influence will increase over time. Leaders that make decisions that are for the good of others around them may face difficulties, but in the long run they will also find that acting morally makes being a leader easier. In some ways this is simply because some decisions are already made for them. If they act in a certain way then they must proceed in that manner, even if the difficulties seem greater than the value from acting in a moral way at the time. If a leader keeps acting in a moral way then 
followers and superiors will trust them more as leaders and they will probably be entrusted with more freedom to lead as they choose.

In this day and age there is an evident lack of willingness to take responsibility for one's own actions. We see individuals who continually take credit for the good ideas of others and pass off the responsibility for mistakes and errors that they make. When leaders take responsibility for their actions whether good or bad they will find that they have more freedom with their superiors. Tichy relayed a story in "The Leadership Engine” about a new leader in the Coke company who had just lost $\$ 11$ million on a venture that he led, and after reporting to the CEO and offering to tender his resignation was shocked that the response was no. The CEO replied something to the effect of "we just spent \$11 million training you why would I want your resignation?” Leaders who take responsibility and lead with morals are valuable in the world today. 


\section{Historical Leadership Shown Biblically}

Servant Leadership:

Christ showed a leadership skill that is not often discussed in leadership today. Servant leadership was the main form of leadership that Jesus used. Jesus showed his disciples how to lead and how to do the work they needed to do. He was willing to do the work himself and that helped inspire those who followed him to do the same things that he did. Christ spent his entire life in this manner. He was the living example of a servant leader teaching others to be servant leaders. One of the most well known examples of where Jesus serves his disciples is when he washes their feet in John 13:120. People were willing to follow Jesus because he put other people first, and looked out for their best interests even above his own.

Jesus stated that he was the example: "I have set you an example that you should do as I have done for you” John 13:15. Today leaders might call it moral action or call it following through on their obligations, but leaders who look out for others and are willing to do the work themselves are followed and respected by many more people than those who put themselves first and have others serve them. Jesus did more than simply serve those he led; he did it because he wanted to, not because he had to. Jesus was willing to serve, but more than that he went out of his way because he knew that the disciples and others would not understand unless they realized that he did it to show love and care for those who followed him.

Jesus did not just train people to be leaders; he taught his disciples to be people who trained leaders. Jesus instilled the need to keep teaching others through serving. Acts 6:2-6 shows that the disciples learned that they needed to serve as well as the fact 
that they had learned delegation. When they found that a task needed accomplishing they raised up new leaders. Jesus had shown the disciples delegation many times; one such instance was Mark 14:12 where he sent them ahead of him to make preparations to celebrate Passover.

Christ set the example that leaders need to be willing to sacrifice for others. Similar to fulfilling obligations and responsibilities, sacrifice means doing what is needed even when it comes at a cost to the person leading. As human beings this is not something that is usually done because people are not willing to suffer if there is an easier way out. In business today it is obvious that many do not understand the concept of sacrifice. People are trying to climb the corporate ladder and even if they understand that they have obligations to those below as well as those above them, they are not willing to fulfill that obligation if there is a cost attached to them. To follow Jesus Christ's example means that a leader needs to be willing to sacrifice even unto death for those who follow them. This is not really required in the corporate world, but the concept is the same. Leaders need to put the well being of their followers even above their position and pay. Leaders need to care more about those who follow them than they do about themselves, because most times those who follow are not as able to look out for themselves, and they trust that the leader will, at least to some extent do so. In Matthew 27 Jesus died on a cross for those who chose to follow him.

Leaders who understand that they need to look out for their followers and realize that they have an inherent obligation for their well being, need to also be willing to intercede for them. In Luke 22:31-32, Jesus intercedes on Simon Peter’s behalf, “But I have prayed for you, Simon that your faith may not fail. And when you have turned back, 
strengthen your brothers”. If as a leader you are in a position to understand what will happen to one of your followers that is not right, you have an obligation to act on their behalf. Shakespeare wrote, "this above all else, to thine own self be true," but for a leader you must be willing to put others before yourself.

All leaders in one form or another are responsible to someone else, or to a group of individuals. Christ showed that submission must play a large part in leadership. In Matthew 26:39 (NIV) Jesus asks, "My Father if it is possible, may this cup be taken from me. Yet not as I will, but as you will.” It was important that as a leader Christ showed submission to his Father. Leaders in the same way need to be in submission to those in authority over them. Submission does not mean that they blindly do what they are told, but rather that after they give their opinions and thoughts they act in the manner that the authority decides without trying to undermine or acting resentfully. There are things that a leader might not know, but that a person with higher authority does; possibly there is information that that leader is not privy to. If one is not submitted, or acts without a full effort or in a manner to undermine, the end result will not be the authorities' responsibility but the person who acted in error. Jesus as a physical man did not want to die on the cross, but he put his needs second to those who followed him and he acted in submission to his Father. He fulfilled his purpose without resentment or anger, with a full commitment to what was asked of him. He set the example not to shirk responsibility, not to cower from a difficult task, rather to love others more than one's own physical life (needs and wants).

Jesus was merciful to those who chose to follow him. In Matthew 5:7 he also encourages others to be merciful. Mercy from a leader may make followers feel 
uncomfortable, but they also feel like they owe the leader something because he did not punish them for what they did wrong. Jesus spent his entire life showing mercy and ultimately he gave himself to show mercy to those who followed him.

Leaders will stand out, simply because of who they are and what they do. In Matthew 5:14 Christians are challenged to be examples: "You are the light of the world." In much the same way a leader is the first thing that people see. Leaders do not try to be noticed, they just naturally attract attention. Most tend to be dynamic people, and if they put others' needs before their own they are the first line of reputation for those they represent. Leaders make mistakes, but many people base their overall opinion of those that the leader represents on the actions of the leader, and what they see of the leader directly contributes to their involvement.

Retaliation as a leader will only lead to problems. Granted, leaders need to have authority and cannot deal with continual problems, but discipline is different than retaliation. Retaliation is generally a form of vengeance, not done to correct or improve, but to hurt and humiliate. Leaders that do this kind of thing generally find that very few are willing to follow them for fear of being attacked if they make a mistake. In Matthew 5:38 Jesus talks about the idea that we need to be willing to accept even abuse without retaliation. Idealistically leaders will deal with very few situations where they are being attacked, but even in those situations they should find a solution without retaliating.

As a leader, one should act in the same manner in private as when others are around. If one acts with consistency, then when they are inevitably seen in private there will not be a discrepancy. As children most hear the statement "Do as I say, not as I do." As leaders it is extremely damaging if one's actions do not line up with their statements. 
Matthew 6:1-4 shows that Christ felt action should not be taken to bring praise to oneself, but because it was needed. In a way the statement is to act as if action is a requirement and not out of the ordinary. When a leader does not tell everyone all the "good things" they are doing they will not look like a braggart, and they will be respected because they do what needs doing without trying to use it to make themselves look good. In Matthew 7:3 Jesus says that one should work on their own problems before accusing others. As humans we tend to see in others that which we like least about ourselves. If a leader runs around punishing and criticizing followers that have the same issues that they have, they discredit themselves and make others unwilling to listen. As a leader there is still a responsibility to fix problems that arise with followers, but in areas where a leader has the same problem they need to act differently.

In Matthew 9:12, Jesus states that the healthy do not need a doctor, but rather the sick. Leaders do not often need other leaders to direct them. They are able and skilled to define and implement what they need to do. To be effective, a leader must be able and willing to deal with those who do not understand the same things they do, and must be willing to help them become motivated. Leaders are best with those who need leading, but if more than one leader is present, leaders will follow the strongest leader. Leaders must have the authority to lead. Oftentimes authority can be given by the followers, but leaders who do not have authority often are worse than ineffective. Matthew 7:28 says that the people were amazed, because Jesus taught as one with authority and not as others. Leaders should also know when the right time is to approach a follower.

The author of this thesis, through reading the Biblical account of Jesus, has come to the conclusion that Jesus showed that a leader should be sure of their mission and 
aware of what is happening around them as well as with themselves. Jesus also showed that a leader should care about those that follow them. In many ways they should love those who follow them and be willing to invest in their followers. Leaders also need to add value to other people, to encourage before disciplining and to help before commanding.

\section{Christ's Use of Modern Leadership Tools:}

Jesus exhibited each of the skills that modern leadership considers paramount. He showed that using them allowed followers to learn and increase effectiveness while at the same time being encouraged. Christ used vision to let others know where he was going and why he needed to do the things he did. He used knowledge to teach those who followed him and rebuff those who attacked and tempted him. Jesus used enthusiasm to push his followers to grow and succeed. Experience gave the proof to others and allowed many to be held accountable.

In Matthew 10:5 Jesus shows vision as he prepares and sends out his disciples to carry on his mission. Jesus knew that he was nearing the end of his time on earth, and that those he had taught to be leaders would need to carry the good news to those who would not hear it directly from him. The disciples could not complete the same things that Christ completed, but he trained them to be able to complete other tasks and then he sent them out. In Matthew 5:17 we see an example of something that the disciples did not have the ability to accomplish when Jesus stated, "I have come to fulfill the law." Jesus knew that he was the only one who could accomplish the task of fulfilling the law. He imparted the vision to the disciples, but they could not fully comprehend it. This vision kept Jesus focused on what he had to accomplish. Jesus was focused on his 
mission. He was the only one who could fulfill the law, but it was a monumental task, and having the vision and knowledge of what lay ahead would make it all the more difficult. Even through the difficulty Christ had a vision even past the cross, where the law was fulfilled for those he loved and called to himself. The knowledge that even through the difficulty those he loved would be saved gave him the drive to go on completing his mission.

In the end, submission to his father was the reason he completed that for which he came. Jesus could see the entire picture; he knew what was to happen and he knew when he needed to show different parts of the vision to those who followed him. In Matthew 9:37-38 he tells the disciples that there is much that can be done but few who would do it. He shows that they would need to grow and build other leaders like he had grown and built them. Jesus knew that the best way to reach others effectively is to reach them with those who know and have a personal knowledge.

Jesus understood that knowledge gave him validity in some people’s eyes. It also allowed him to be much more effective in his leading. When Jesus was tempted in the wilderness, (Matthew 4:1-12), he showed that with knowledge he was able to protect against manipulation and temptation. Even as Satan tempted Jesus in the wilderness, leaders are tempted in many ways. Never will a leader have the same consequences for failure, but knowledge can still protect one against manipulation. Jesus also showed that he had the knowledge to be an example. In Matthew 5:14, he tells the disciples that they would be the "light of the world," that they would stand out and with their knowledge and actions they would be an example as he was the example. With knowledge one can direct and encourage. By being an example one holds a responsibility, and with that 
responsibility one can find both pain and joy. Jesus showed many times that many would fall away under the pressures of this life, that persecution and challenges would push people into failure. Leaders will go through the same situations and fall to the same pressures. Knowledge is one of the best defenses. If a leader knows that they will be attacked and persecuted, they can prepare themselves for it so that when it happens they can stand and fight back. Knowledge of when to do a task is also important, especially in times when one falls under attack. In Matthew 9:15 Jesus makes a statement that shows that certain things need to be done in certain times, and often people do the appropriate thing at the wrong time. Leaders often do not know the right time to do something. If they are under attack from someone they may fight back at the wrong time and end up in a worse position than if they had remained quiet until the time was right to voice their opinion. Proverbs 13:3 states that "He who guards his lips guards his life, but he who speaks rashly will come to ruin.” This is the same concept that Christ taught, and it often is true with leaders.

Christ used enthusiasm much like it is used today to propel those who followed to the point where they were willing to do what was needed because it was exciting and needed. As we have seen, enthusiasm can be contagious; if a leader is enthusiastic their followers for the most part will be as well. In Matthew 4:19-20 Jesus shows his enthusiasm, that there is something more to fish for than that found in the sea, encouraging Simon called Peter and Andrew his brother to follow him. If a leader wants to let those who they lead succeed, they need to use enthusiasm to encourage. If they are depressed and dejected then their followers will act in a similar manner. Matthew 5:14 tells that the salt is only useful if it is salty, much the same as a leader that does not 
encourage, saltless salt is useless. Individuals who cannot motivate those who follow them are not leaders; they are individuals who may hold positions of authority. If they do not encourage and act enthusiastically then they do not lead. Leaders, as we have examined, are most successful when they build up and support others before themselves. Enthusiasm is not always happy and positive, and many people including leaders forget that negative enthusiasm can be effective and useful in the right context.

Experience gives whatever a leader says credibility to many who listen. Jesus shows that experience is needed to lead people. Matthew 4:23-25 states that Jesus went out and began teaching and preaching, healing sickness and disease, and then people came as they heard about him. His experience gave him credibility to many people. This is the case with many followers. They need to see before they believe and do. Jesus spent time doing many things, and some individuals may have understood without his action, but that action showed that he had the experience, and brought credibility to what he said. Matthew 8:5-13 shows us a leader of men who was talking to Jesus. Why did the Centurion understand that Jesus knew about authority? Why did he believe that Jesus was who he said he was and had the power he had? The answer is that the Centurion had heard what Jesus had done (experience) the people he had healed. The Centurion knew what Jesus could do and what he had done, the Centurion was able to believe. Jesus showed that experience also validates people. In Matthew 11:18-19 Jesus deals with the rumors and slanderous statements said about John and Himself, by simply saying, "but, Wisdom is proved right by her actions.” 


\section{CH. 3 COMPARISON OF MODERN AND BIBLICAL LEADERSHIP}

Leadership today has changed significantly over what was considered leadership forty, even twenty years ago. The current understanding that managers are in a different role than leaders has facilitated the changes we see in leadership today. This distinction has also facilitated the process of educating leaders how to be more effective. In many ways leadership today more closely emulates the historical view of leadership found in Jesus Christ, but at the same time there are several core differences that might aid in the improvement of the overall concept of leadership today. As has been discussed, Christ used each of the tools that are considered part of modern leadership, but he also used other skills and had a character trait that most leaders today do not possess. Overall, leadership has come a long way in the last twenty years, but there are several areas that could be improved upon.

Today leaders use vision to inspire and direct those who follow them. Two major issues limit most leaders’ visions. First, leaders are often biased by their own personal vision even when they should have different priorities. Secondly, most leaders have short-term visions that they impart. If they do have a long-term vision it often is kept to themselves. Leaders feel that they decrease their control when they give away all of the information to those who follow them. Often business leaders are afraid of losing their 
job to someone else who steals their ideas. This attitude that leads to limited long term visions often can significantly limit the potential of a leader.

They may train excellent followers, but they will never train other leaders. Christ had the longest vision of a human leader that has ever been seen. He was not afraid of someone usurping his position or taking his job. One reason was because his ultimate job was one that very few people would undertake even if offered to them.

The main reason was that he was training those who followed him to lead others and not just to follow him. Jesus wanted his followers to be able to do his job when he went on to his next task. In many ways leadership may seem like the ultimate pyramid scheme of all time, but the fact is that stronger leaders will always lead and teams with more leaders have more ideas, more drive and stronger visions.

Knowledge is another part of modern leadership, Knowledge of leadership, people and of appropriate subject matter increase the effectiveness of a leader. Today most people are very specialized in one area or another; even if a leader has all the knowledge in the world about one subject area there are still many factors that they do not know. Leaders today need to realize that they do not have all the answers, because at that point they can develop other leaders, lean on other people's knowledge and support those who have the knowledge needed.

Human understanding is limited, our knowledge of people is partial, and we relate differently to almost every individual we know. Our understanding of subject matter is at best partial, and much of what we think we know is information that has been passed down to us and we simply trust that its true. Finally, leaders' knowledge of how to lead is incomplete. In fact, the best leaders realize that they never stop learning how to lead or 
how to live. Christ, by comparison, knew how people thought and knew how to lead individuals as well as groups. Look at his experience, the people that came to listen and those who believed he was who he said he was. He had complete knowledge of the subject matter; he was discussing with experts as a child and those who he discussed with were amazed (Luke 2:47). From Jesus Christ's example leaders need to increase their knowledge and act humbly.

Leaders, when they are not in the best of moods, tired or any one of a number of different factors, often try to force enthusiasm. Unfortunately many leaders today are enthusiastic about the task and not the people. Even though this is beneficial it does not increase followers' enthusiasm if other things need addressing. Overall, most leaders do not know how to use enthusiasm. Ideally leaders should spend time learning people and understanding when and where to encourage and be enthusiastic.

Jesus knew when to be enthusiastic and what kind of enthusiasm to use, whether positive or negative. He had the knowledge about the people it would affect and how it would affect them. Jesus had other answers that many leaders today do not possess. He knew his mission, he knew his goal and over all else he was submitted. Many leaders today think that submission means they are not a leader, but to be a leader you need to know your mission, goal and you must submit to those in authority over you. In business you must submit to your boss and, if not him, then the owner or owners. If a leader is an owner then they must submit to the needs of their customers. If a leader is not submitted then they really will not be enthusiastic in the long run, or know how to deal with their followers or peers. 
Experience is another modern day leadership tool that Christ used. Christ gained experience by doing. He was out preaching and teaching people. He was actively going somewhere all of the time to gain experience. In people's eyes he had experience, and his followers knew that he did. His experience validated who he was to many of those who did not believe, like the Centurion. Experience will often validate a leader to those around them. Many leaders have limited experience, which can lead to conflicts over control. This is because many really do not know how to lead. These people want to be in charge and simply control other people. The best leaders need to be continually learning about leadership and how to lead. Experience does not always validate a leader, however experience will allow them to decrease conflicts over control. If a leader has technical expertise in a totally different field they may not find any validation at all from their experience.

The propagation of other leaders is often seen as a threat today. However, the more people who are able to lead the better off a company or group will be. Leaders who micro-manage like so many in the business arena today leave a group unable to function without them if another priority comes along, or if they are sick. Also many leaders today do not realize that at some point certain tasks should be passed to followers. Many leaders see this practice as a threat to them and their position. Christ saw it as key to empower those who follow you, to teach them to lead, and he taught his disciples to do the same. The disciples, when leading a church, would raise up leaders to take responsibility for major tasks because they realized that they needed to be focused on other things. When leaders teach others to lead the overall benefit multiplies exponentially. 
Leaders need to put others' needs first. Leaders have a major responsibility to look after those who follow them. Many business leaders and community leaders have little to no regard for those who follow them. In 2008 the Tulare County Board of Supervisors gave itself almost a 6\% pay increase in the midst of laying off almost 500 people and only were willing to rescind it when the public spoke up in outcry. Many will demand a follower or employee work normal hours even if they are willing to work more hours to be given some flexibility in their schedule. Many seek only to better their own personal position and as a matter of course they weaken their leadership ability. Christ thought of others' before himself all of the time. He put others needs and hopes first. If leaders cherish others before themselves people will want to follow them and will go out of their way to gain that leader's trust. Look at businesses today, we have disloyal employees who show up late, do little work and steal from the business, but is that the problem or the symptom? It is only a symptom of leaders who are trying to make all they can from those who follow them, without investing in the person or looking out for their needs.

Leaders have a responsibility to their followers, but more than that they have a responsibility to those they follow. Leaders today often do what they feel is necessary, or what they deem is best for themselves. Leaders need to submit to their authority, they need to hold themselves responsible to authority above them, or else they will not be effective and will damage the overall goal of the organization they belong to. Jesus was submitted to his father. He submitted totally unto the point of death. 


\section{CH. 4 ANALYSIS AND METHODOLOGY}

In order to discuss what leadership is today an analysis of what recent authors have composed in regards to leadership is necessary. Looking at what different authors have written about leadership gives insight into the overall picture of what leadership is and how it should be used.

In researching current leadership an overall trend emerged of authors identifying a need for education in how to lead, leadership skills and how to perpetuate leadership. By looking at what has been written about leadership and the education of leadership today it is possible to define in a broad sense what leadership actually is. However, because there are non-tangible elements of leadership, the study and implementation of leadership will always be more than a three step process.

Look at what has been learned about leadership. Many authors have emphasized a formal education of leadership, like Smarkusky (2004), in order to develop greater leaders for the future. Most advocate an education of leadership through team projects. Wazler (1991) emphasized the need for social vision and drive to complete the task of education. Aguilar (1994) was more specific by saying that ethical education of leadership is necessary. Wilcox (1956) used a quote by Ezra Taft to emphasize social responsibility in governmental leadership. “The supreme test of any government policy, 
agricultural or other, should be, 'How will it affect the character, morals, and well-being of our people?” Wilcox also focused on knowledge and drive. To analyze the impact that social vision and responsibility play in education today one should look to public schools, for example, and the fact that many programs have been developed for the community's needs. Cunningham (1993) wrote about educational vision and the drive needed to achieve that vision, he also focused on building knowledge. Scott (1973) also focused on the education of leadership and the drive to implement true education. Stewart (1978) and Lane (1987) wrote specifically about the formal instruction of leadership in society today. Education becomes a valuable resource to perpetuate the growth of leaders, and as the value of true leaders is more fully ascertained formal education of leadership will become more necessary.

Many have focused on individual growth, but authors on leadership agree that vision, an end goal, is a core part of modern leadership. Tichy (1997) compared the modern leader with what used to be considered a leader. He renamed what used to be leaders as managers. Tichy also dealt with knowledge and drive. However, the main focus of Tichy was in terms of people. He wanted to show how to know people and encourage them to reach a goal. Maxwell (1998) focused on the same areas that Tichy did, however he emphasized moral and ethical responsibility to those in authority and to one’s followers. Nanus (1989), Whicker (1996), Wall (1992), Fitzgerald (1997) and Maccoby (1933) all focused mainly on vision, coupled with drive, motivation or experience. Vision and drive have become two of the most highly recognized leadership skills. Vision is the goal needed and drive is the ability to move people towards that goal. If leadership is the act of influence then these are core parts of leadership. 
Van Creveld (1985) discussed the need for specific knowledge, vision and drive in an area that does not allow for mistrust or interpretation. Van Creveld's book is important to show that leadership in "high tension or stress" situations is much the same any given situation; the main change is that it depends more on trust and employs a different form of communication.

Taylor (1989) emphasized the distinction between a manager and a leader, and sought to ensure that readers understood that today there is a distinction between people associated with these two titles. Ideally a leader can exist as a manager as well, but Taylor made the point that individuals who can operate efficiently in both areas are not frequently seen.

Many authors write that knowledge is still a vital part of being a leader. Pearce (1995) argued that today with the access to general knowledge that is currently available a leader does not need nearly the expertise that leaders in the past needed. Pearce argues that as a matter of course the strongest leaders will not be individuals with subject matterspecific knowledge but individuals with knowledge of how to lead individuals and groups to complete a task. Schmidheiny (1992), in somewhat of a contrast to Pearce, proposed that leaders need to seek knowledge, that regardless of what an individual knows about leading they need to keep learning and searching. He proposed that with the effort to gain knowledge in general, leaders will better themselves as well as preparing for the future.

As a matter of course many businesses have taken to the idea that leaders are needed. There has always been some form of vision in business, but the concept of vision in leadership is that all levels of the organization know the leader's vision. This 
form of vision, where many more people in the company are involved in the overall vision, has become more prevalent and should become commonplace in the future. Knowledge of how to lead is becoming the next major shift in business. Education of leaders is taking place in public schools, companies are spending millions of dollars to train their employees how to work in teams, and the companies that are succeeding have larger numbers of true leaders than those who are failing. Companies have begun teaching their leaders how to use knowledge and experience to increase their capabilities, but the major leadership tool that will become increasingly necessary in the future is the ethical and moral action of leaders. Leaders in the future will be sought after because of what they are able to accomplish, but if they are not known to be moral and ethical individuals, people will not follow them and companies may seek leaders less able but more reliable. With the direction of today's society there will be a greater call for the reliable leaders, because they can perpetuate their values to their followers and those in authority over them can trust them.

Seeing implementation of leadership education in companies, schools and government has increased the perceived value of leadership today. The need to increase leadership skills and continue learning how to lead brings many individuals to ask what is the next step in leadership. Perhaps the next step is for leaders to realize that they need to put the needs of those who follow them before their own needs. 


\section{CH. 5 CONCLUSIONS AND RECOMMENDATIONS}

Leadership today has become a vibrant area of learning and exploration. Until the early 1980’s it was simply a character trait that businesses sought and many people felt that leaders were born leaders. Today we know that leaders are an invaluable part of business, and that individuals learn to be good leaders. We also know that the best leaders are the ones who keep learning how to lead, as well as simply continuing to learn.

With the conclusion that the best leaders keep learning and learning to lead, leaders today must look for different things to learn and become proficient. Leaders must continue to see the best possible avenues to lead other individuals and to grow their own leadership skills. Many leadership skills used today have been found by looking at individuals from the past and evaluating how they lead others. With that in mind the historical example of leadership found in Jesus Christ has been evaluated to see if any skills that he used can pertain to modern leadership. There are two main areas where leaders today can use the example of Jesus Christ's leadership to make improvements in their leadership capabilities. The first is in responsibility and servant leadership, and the second is in the area of submission to authority. 
Leaders today continually seek to better their position. This really is not just an issue for leaders, but leadership carries with it an inherent responsibility to look out for those who follow, or who simply do not have the ability to look after themselves. Leaders in the long run find that people will refuse to follow a leader who places their own benefit over others when there is another option.

Organizational growth occurs when leaders take responsibility for their followers and ethically think about what is needed for the whole organization, not just themselves. Many leaders do not understand ethics and are not willing to employ them in their work.

Leaders need to submit to higher authority. When we have leaders that do not submit we often find major conflict in businesses. Even if the leader is quiet about their personal rebellion to higher authority the simple mindset is a hindrance to the business. If a leader submits to authority then their visions will not be in conflict, their motives will not be skewed and overall the business will accomplish more by acting in harmony.

Leaders are the example as well as the driving force behind any group. Leaders set the example. A leader's followers will be in conflict with the leader's authority if they see that the leader is in conflict with their authority. This may not always be the case, but a leader will have an impact on those that follow them; regardless of the extent of the impact, it will occur. 


\section{BIBLIOGRAPHY}

Abraham Mazlow. 1971. The Farther Reaches of Human Nature Viking Books. Harmondworth, NY.

Aguilar, Francis J. 1994. Managing Corporate Ethics: Learning from America's Ethical Companies How to Supercharge Business Performance. Oxford University Press, Oxford and New York.

Barna Research Group, Online posting of research done for resource use by pastors and other individuals in Christian Ministry.

http://www.barna.org/

Cunningham, William C. and D. W. Cresso. 1993. Cultural Leadership: The Culture of Excellence in Education. Allyn \& Bacon, Needham Heights, Massachusetts.

Fitzgerald, Catherine and Linda K. Kirby. 1997. Developing Leaders: Research and Application in Physiological Type and Leadership Development. Davies-Black Publishing, Palo Alto, CA.

Lane, John J. and Herbert J. Walberg. 1987. Effective School Leadership: Policy and Process. MrCutchan Publishing Corporation, Berkeley, CA.

Lau Tzu, 1972 (Translated Version Copyrighted and Printed). Tao Te Ching (The Way and Its Power). Vintage Books, USA.

Maccoby, Michael. 1933. The Leader: A New Face for American Management. Simon and Schuster, New York, NY.

Maxwell, John C. 1998. The 21 Irrefutable Laws of Leadership. Thomas Nelson Inc. Nashville, Tennessee.

Nanus, Burt. 1989. The Leader's Edge: The Seven Keys to Leadership in a Turbulent World. Contemporary Books, Inc., Chicago IL. 
Pearce, Terry. 1995. Leading Out Loud: The Authentic Speaker, the Credible Speaker. Jossey-Bass Publishers, San Francisco, CA.

Schmidheiny, Stephen. 1992. Changing Course: A Global Business Perspective on Development and the Environment. Massachusetts Institute of Technology Press. Massachusetts

Scott, Roy V. and J.G. Shoalmire. 1973. The Public Career of Cully A. Cobb: A Study of Agricultural Leadership. University and college press of Mississippi, Jackson, MI.

Smarkusky, Debra L. and Harold H. Smith. 2004. Team projects throughout the curriculum: course management, teaching initiatives and outreach Journal of Computing Sciences in Colleges. Volume 19, Issue 5 ISSN: 1937-4771

Stewart, Bob R. 1978. Leadership for the Agriculture Community: Activity Guide. Edwards Brothers Inc. Columbia, Mo.

Taylor, Robert L. and William E. Rosenbach. 1989. Leadership: Challenges for Today's Manager. Nichols Publishing, New York, NY.

Tichy, Noel. 1997. The Leadership Engine. HarperCollins Publishers, Inc. New York, New York.

Van Creveld, Martin L. 1985. Command in War. Harvard University Press, Massachusetts and London, England.

Vernon, Scott. Professor at California Polytechnic State University. Information from Agricultural Education (AGED) 404.

Wall, Bob et. al. 1992. The Visionary Leader: From Mission Statement to a Thriving Organization, Here's Your Blueprint for Building and Inspired Cohesive, CustomerOriented Team. Prima Publishing, Rocklin, CA.

Walzer, Norman (ed). 1991. Rural Community Economic Development. Praeger Publishers, New York, NY.

Whicker, Marcia L. 1996. Toxic Leaders: When Leaders Go Bad. Quorum Books, Westport, CT.

Wilcox, Walter W. 1956. Social Responsibility in Farm Leadership: An Analysis of Farm Problems and Farm Leadership in Action. Federal Council of the Churches of Christ in America, New York, NY. 